CIENCIAS MARINAS Y AMBIENTALES

\title{
Evaluación técnica de las embarcaciones de pesca de arrastre del Caribe colombiano: recomendaciones para mejorar la eficiencia de la flota
}

MARINE AND ENVIRONMENTAL SCIENCES

\section{Technical assessment of shrimp trawler vessels in the Colombian Caribbean: recommendations for improving fleet efficiency}

\author{
Jairo Altamar*** §, Harley Zúñiga*, Luis M. Manjarrés-Martínez* \\ * Laboratorio de Investigaciones Pesqueras Tropicales - Universidad del Magdalena, Colombia \\ ** Doctoral Program in Marine Sciences and Environmental-Universidad de Aveiro, Portugal \\ §jaltamar@unimagdalena.edu.co,hzuniga@unimagdalena.edu.co,lmanjmart@hotmail.com
}

Recibido: 06 de Febrero 2013 - Aceptado: Febrero 22 de 2014

\begin{abstract}
Resumen
A partir de un análisis crítico de la configuración tecnológica actual de las embarcaciones y los equipos de pesca de la flota industrial de arrastre de camarón que faena en el Mar Caribe de Colombia, se determinó la viabilidad de introducir cambios tecnológicos que tendrían un impacto positivo en la eficiencia de esta flota, actualmente inmersa en una situación de veda económica a la que han contribuido los altos costos de operación. Los resultados indican que las relaciones de transmisión están mal diseñadas, y un funcionamiento ideal se lograría reduciendo el número de dientes de la rueda de estrella conducida. Además hay un sobredimensionamiento en la potencia y las dimensiones de las embarcaciones, con respecto al tamaño de los equipos de pesca actualmente utilizados. La alternativa sería diseñar equipos ajustados a la potencia instalada, construidos con materiales más resistentes y livianos, que disminuyan el consumo de combustible y el impacto sobre la pesca acompañante.
\end{abstract}

Palabras clave: ahorro de combustible, camarón, Colombia, embarcaciones pesqueras, pesca de arrastre.

\begin{abstract}
From a critical analysis of the current technological configuration of boats and fishing equipment for the industrial fleet of shrimp trawl fishing in the Caribbean Sea of Colombia, we investigated the viability of introducing technological changes that would have a positive impact on efficiency of the fleet, currently embroiled in a situation of economic restraint due to the high operating costs. The results indicate that the transmission ratios are poorly designed, and an ideal performance is achieved by reducing the number of teeth of the driven sprocket. There is also an oversizing in the power and dimensions of the vessel, regarding the size of the fishing equipment currently used. The alternative would be to design fishing gears adjusted to the installed power, built with resistant and lightweight materials that reduce fuel consumption and the impact on by-catch.
\end{abstract}

Keywords: Colombia, fishing boats, save fuel, trawling, shrimp. 


\section{Introduction}

The efficient use of energy has been a central issue in many studies on fishing gear technology. After the energy crisis of the 70's, the goal of fishing technology was to decrease the use of fuel by reducing friction; however, after the fall of fuel prices in 1985, efforts were centered on improved selectivity and reduced by-catch (Kasper, 1983; van Marlen et al., 2003). Recently, energy saving has once again become a topic of utmost importance and new studies on this subject are being carried out (van Marlen et al., 2008). In the specific case of trawling fishing vessels, a greater fuel consumption is required due to the use of trawl nets that represent $60 \%$ of the forward resistance (Wileman, 1984). Some modifications have focused on reducing the area of the nets by using larger meshes in the front portion (wings and square), which decreases friction without affecting the area of the net mouth, and therefore the capture efficiency (Parente et al., 2008). Some materials have also been replaced by others that are more resistant and have a smaller diameter, which leads to significant reductions in fuel consumption (Zúñiga et al., 2006).

In the Colombian Caribbean, the commercial shrimp exploitation started in 1966 with three vessels; later, in 1968, a small industrial fleet was established with the creation of a company called "Vikingos de Colombia S.A.", and the arrival in 1969 of ten Florida-type vessels built in Colombia (Martínez, 1978). Initially, two trawl nets were used, one on each side of the vessel, but in the 80 's a significant technological innovation was introduced by Korean shipowners, which consisted of using two nets on each side (Piñeros $\&$ Sieguert, 1981). A greater area was then swept, thus simultaneously increasing the capture efficiency of the fishing equipment.

In the Colombian Caribbean, the shrimp trawl fleet reached a total of 100 fishing vessels in the 80 's. Currently, only nine are actively fishing. This reduction of the fleet has been caused by a concurrence of various factors: high operating costs (principally fuel), decrease in international shrimp prices, high supply of farmed shrimp, revaluation of the Colombian peso compared to the American dollar (Zúñiga et al., 2004; 2006) and a historical decrease of shrimp landings that has been reported since the end of the 80's (Mora, 1988).

The previously described situation makes recommendable the introduction of technological innovations directed at making this type of fishing more efficient and sustainable, along with the implementation of management strategies for the exploited resources. Therefore, the purpose of this study was to perform a critical analysis of the current technological configuration of the vessels that make up this fleet to evaluate the viability and pertinence of introducing changes that would result in greater technical and economic efficiency as a factor for better profitability and sustainability.

\section{Methodology}

To identify the shrimp trawling fleet that operates in the Colombian Caribbean, information was collected from the technical characteristics of the vessels and their fishing trawls through direct observation complemented with interviews to shipowners, fishing captains, sailors, net handlers and operation managers of the fishing companies. The secondary information came from two sources: a) certificates issued by the governmental agency that regulates maritime aspects in Colombia ("Dirección General Marítima"), and b) operating records of the vessels and databases of the patents emitted by the Colombian fishing Authority at that time (INCODER). Information from other technological studies previously carried out in the area were also used (Buelvas \& Guerrero, 1996; Viaña \& Manjarrés, 2004).

The following technical characteristics of the fishing equipment used by the fleet were considered for the purpose of drawing the respective designs: (1) material, diameter and length of the ropes; (2) material, chemical treatment, twine diameter, size and quantity of meshes in the upper and lower edges of the panels, fall and cutting rate 
(for each panel of the net); and (3) materials and arrangement of the gear rigging (length, diameter and weight of the warps and the bridles, sinkers, floaters and otter trawl doors, indicating the arrangement of the chains of the towing system).

For a total of 80 vessels, all the mechanical transmissions coupled to the winches were checked (Rice R800 D and Mc. Elroy-Hoists 505) for establishing the gear ratios. From this, a kinematic scheme were drawn (Dobrovolski, 1980) to recommend modifications aimed at reaching optimal hauling speeds at ideal rpm levels in the engine power take-off (PTO) (Czekaj, 1988). Likewise, the ideal vessel required to tow the most-used trawl in 1995 (46'semi-balloon model) was compared with that of 2010 (37' Korean model). To do so, the engine power was calculated (Koyama, 1971; Okonski \& Martini, 1987; Bucki, 1984) along with the forward resistance of the trawl using a Japanese formula (Bucki, 1981) and the dimensions of the ideal vessel was determined using the equation that relates the Admirality coefficient with the towing speed, the power and the displacement (Bonilla de la Corte, 1979). The sequence of the equations used is as follows:

With Eq. (1) and (2), the forward resistance of the trawl FXA and the traction force of the vessel (FTA) were calculated.

$$
\begin{gathered}
F_{X A}=191 \frac{d}{a} V_{a}^{2} A_{t} \operatorname{sen} \alpha \\
F_{X A}=F_{T A}=\frac{75 H P_{a}}{V_{a}}
\end{gathered}
$$

where $d=$ twine diameter $(\mathrm{mm}), \mathrm{a}=$ bar length of the mesh (mm), $A_{t}=$ fictitious area of the net $\left(\mathrm{m}^{2}\right)$, $H P_{a}=$ motor power needed to tow the fishing equipment (HP), $V_{a}=$ towing speed $(\mathrm{m} / \mathrm{s})$ and $\alpha=$ angle of attack.

With Eq. (3) the fictitious area of the net $\left(A_{t}\right)$ was calculated

$$
A_{t}=\left(\frac{N_{s}+N_{i}}{2}\right) N_{p}(2 a)^{2} \mu_{1} \mu_{2}
$$

where $N_{s}$ and $N_{i}=$ number of meshes of the upper and lower edges of each panel, respectively; $N_{p}=$ height (in meshes) in each panel or section; and $\mu 1$ and $\mu 2=$ horizontal and vertical hanging ratio ( 0.5 and 0.866 , respectively).

To calculate the engine power, Eq. (4) was used:

$$
B H P=\frac{H P_{a}}{\eta_{p} \eta_{u} \eta_{m}}
$$

where $B H P=$ brake horsepower, $\eta_{p}=$ propulsion performance coefficient, $\eta_{u}=$ engine performance coefficient (by use) and $\eta_{m}=$ sea-state related performance coefficient.

To calculate the engine power needed, equivalent to the brake horsepower (BHP), the forward resistance for the four nets was calculated. This last value corresponds to the total pulling force exerted by the fishing equipment (Bucki, 1984).

To calculate displacement ( $\Delta$ ), Eq. (5) was used:

$$
\Delta=\sqrt{\frac{\left(C_{a} B H P\right)^{3}}{V_{c}^{9}}}
$$

where $\Delta=$ displacement $(\mathrm{Tm}), V_{c}=$ cruising speed (knots) and $C_{a}=$ admirality coefficient.

The parameters for the vessel dimensions were established using the proportions of the principal measurements and Eq. (6)

$$
\begin{aligned}
& \frac{L}{M}=(2.42 \approx 3.10) \\
& \frac{M}{C}=(2.16 \approx 2.78) \\
& \Delta=L M C C_{b} \gamma
\end{aligned}
$$

where $L=$ length, $M=$ beam, $C=\operatorname{draft}, C_{b}=$ block coefficient ( 0.5 for fishing vessels) and $\gamma=$ specific weight of sea water $\left(1.026 \mathrm{Tm} / \mathrm{m}^{3}\right)$.

To determine the dimensions of the ideal vessel, the displacement was calculated using a cruising speed of 10 knots and an admiralty coefficient 
of 80 (Bonilla de la Corte, 1979). The midpoint in the ranges of the length/beam and beam/draft ratios were also used.

\section{Results and discussion}

\subsection{Size and fleet distribution}

From 1985 to 2012 the shrimp trawl fleet that operates from Cartagena decreased by $88.75 \%$, going from 80 to 9 vessels, of which 5 operates in the South and 4 in the North. A fleet of smaller vessels operates exclusively from Tolú from 1982, covering the outer zone of the Gulf of Morrosquillo and its surroundings. Currently, this fleet is made up by 6 vessels. Since both fleets have been experiencing technological changes, it is to be expected that such modifications directly affect the captures (Fuentes \& Portugal, 1973). In fact, the variability of the volumes and composition of captures have a direct effect on the productivity of the shrimp fleets (García-Caudillo \& GómezPalafox, 2005).

Shawyer (1997) analyzed the costs of operation and profitability for a typical shallow water shrimp vessels, concluding that the high fuel consumption per hour of trawling is the most important determinant fin the low productivity of this fishery. In support of the aforementioned, Zúniga et al. (2006) stated that more than $50 \%$ of this vessels obtained negative earnings in the period 20042005. Consequently, the main company (Pesbocol S.A.) closed in 2005.

\subsection{Vessels characteristics}

All the vessels are "Florida-type" trawlers, which have a V-shaped hull. These trawlers use four nets, two on each side, except for the six vessels operating from Tolú, which only use one net on each side. The lengths of these vessels fluctuate between 13.16 and $24.84 \mathrm{~m}$, with a modal value of $21.33 \mathrm{~m}$. A census of the Cartagena-based fleet carried out in 2003 (Zúñiga et al., 2004) showed that 41 out of 53 vessels $(77.4 \%)$ had steel hulls, 11 fiberglass ones and only one was built of ferrocement. According to the same survey, Tolú-based trawlers have a length of $13.16 \mathrm{~m}$, fiberglass hulls, and engine powers between 165 and $520 \mathrm{HP}$, being the most used $(43.4 \%)$ the $450 \mathrm{HP}$ engine. The leading brands in both fleets are Caterpillar, Cummins and Yanmar. Regarding the deck machinery, Mc. Elroy Hoists 505 was the most used winch type, being used in 24 vessels (45.3\%). Another significant fraction of the fleet $(37.7 \%)$ used a Mexican-built winch (Rice, model R800 D), and only one vessel has an engine of brand Stroudsburg. The Tolú fleet uses Japanese-built hydraulic winches.

The fleet has undergone structural changes directly related with the vessels. Among them, the disappearance of several wood hulls that were active until 1979 and the incorporation of hulls built of other materials, such as fiberglass or ferrocement in fewer cases, should be highlighted. Similarly, the increasing engine power should be noted among these changes. In 1975, the majority of engines had powers between 300 and $350 \mathrm{HP}$; in 1990, this interval increased to 400-450 HP. By contrast the modal dimensions of the vessels (20$22 \mathrm{~m}$ ) have remained the same over time (Piñeros \& Sieguert, 1981).

\subsection{Gear rigging}

On average, the length of the towing warp wound around each drum of the winch is $450 \mathrm{~m}$. This warp is made of galvanized steel 5/8-inches cable, reinforced with a $6 \times 19+1$ textile fiber core. (Camesa, 2000). The bridles are between 54 and $72 \mathrm{~m}$ long and made of $1 / 2$-inch steel cable, with the same characteristics of the towing cable. The interior wings of the two nets are attached to a kind of "sled", called "skate" or "torpedo", which is towed simultaneously with the doors. Both the skate and the torpedo are $1.87 \mathrm{~m}$ long and $0.87 \mathrm{~m}$ high. The skate is built of sheets of iron, and the torpedo is built with metallic tubes (Figure 1).

The two trawl nets on each side of the vessel are kept open horizontally by two otter doors. These doors are flat, rectangular boards with wide shoes, made with five vertical and four horizontal wooden plates separated 2 inch each other. The chain backdrop system attached to the towing cable is composed 


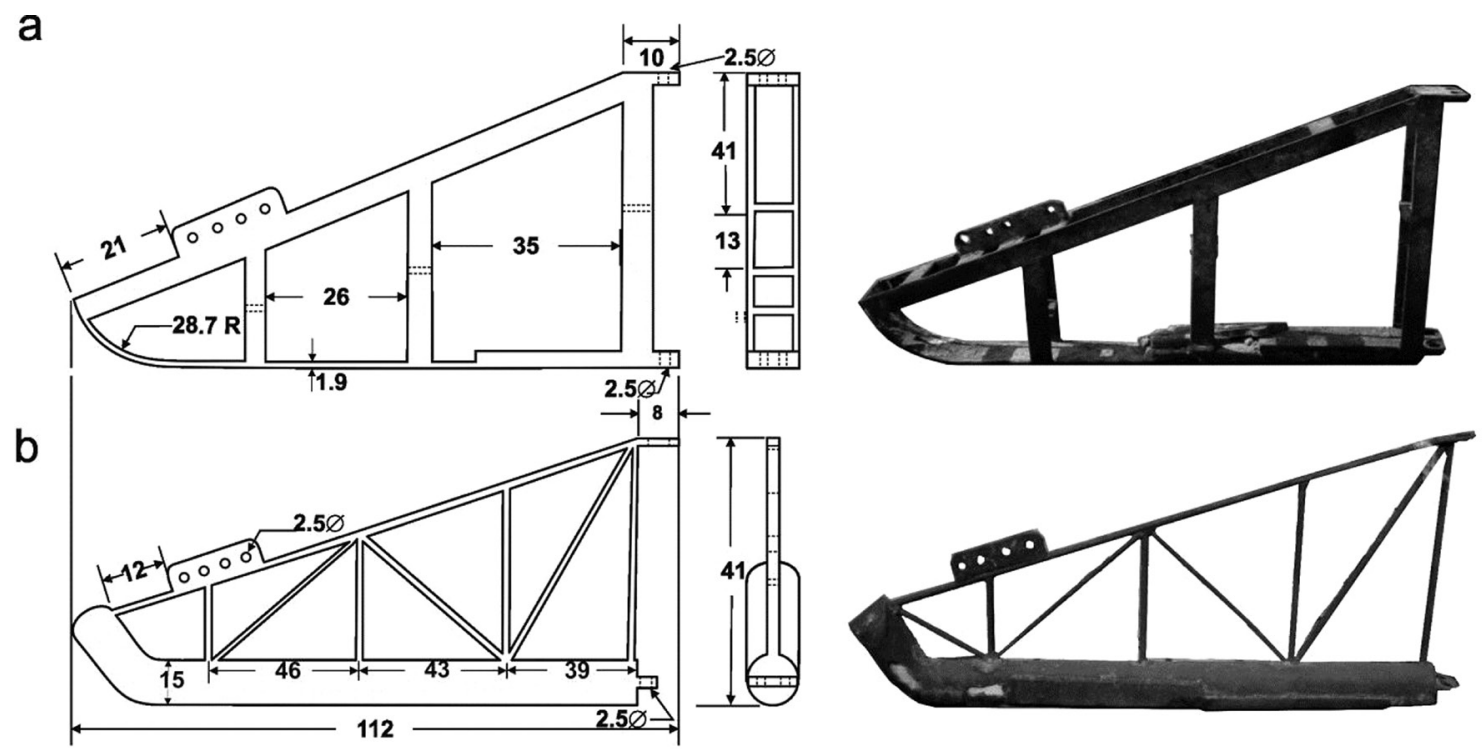

Figure 1. Scheme and photograph of a) skate, and b) torpedo, which support the inner wings in the twin shrimp trawl.

of $1 / 2$-inch chains that allow for the adjustment of the attack angle by moving the towing point, lengthening or shortening the chains. This point is adjusted leaving an extra chain link in the upper front branch with regards to the lower branch, while one or two more chain links are left in the upper back branch with regards to the lower back branch. This link arrangement varies according to the preferences of each captain. In fact, the following arrangements were found: $20-19$ and $37-36,17-17$ and $34-34$ and $16-16$ and $35-35$ (Figure 2). The size of the otter door is specified by the length in feet and the height in inches. . Using this form of measurement, the most-used configurations for Cartagena fleet are 8'x36" and 9'x36", whereas the Tolú trawlers, which only have one net on each side, use smaller doors (6'x28").

\subsection{Trawling nets}

At first, the Cartagena fleet used one trawl on each side, made out of polyamide and with headrope lengths (HRL) between 65- to 90-feet. Later, in the decade of the 80 's, this fleet began to use flat or semi-balloon trawl nets (two on each side), made out of polyethylene (PE) and with 42- to 46feet HRL (Viaña \& Manjarrés, 2002; Buelvas \& Guerrero, 1996). Currently, smaller trawl designs, the so-called "Japanese" (37 feet) and "Korean" (42 feet) models, are used. This reduction in trawl size was aimed at decreasing the forward resistance and, consequently, the rate of fuel consumption (Arzuaga \& Torres, 1990). The Japanese net is used more frequently, even by the trawlers operating from Tolú, but these ones use bigger trawls (49 feet).

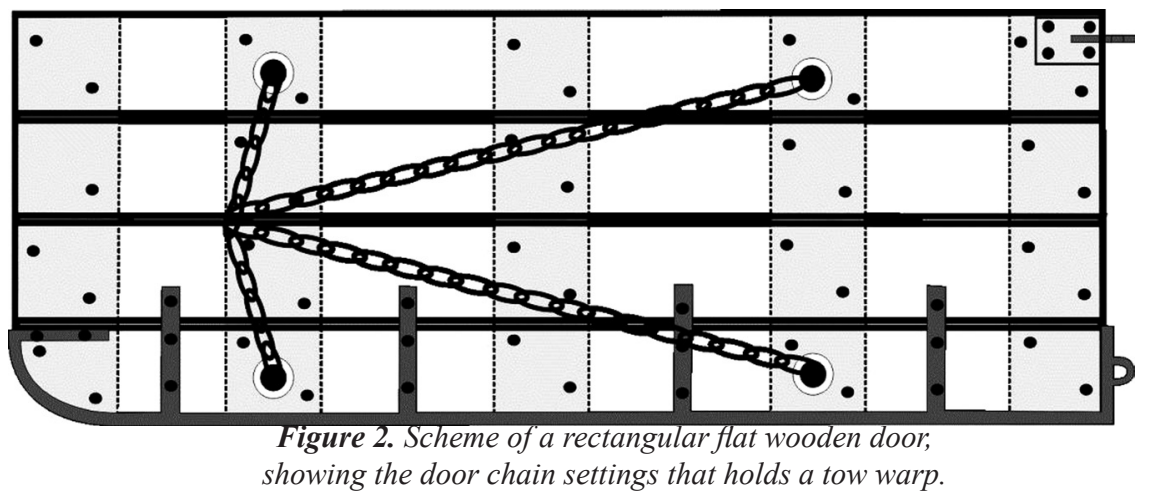


Table 1. Length, diameter and material of the ropes of Japanese and Korean trawling nets models.

\begin{tabular}{ccccc}
\hline Model & Rope & Length & $\begin{array}{c}\text { Diameter } \\
\text { (inch) }\end{array}$ & Material \\
\hline \multirow{2}{*}{ Japanese } & headrope & $12.8 m+1 m$ from each end to the wire rope thimble & $1 / 2 "$ & combined rope ("tralla”) \\
& footrope & $14.8 m+1 m$ from each end to the wire rope thimble & $1 / 2 "$ & combined rope ("tralla”) \\
\multirow{2}{*}{ Korean } & headrope & $11.27 m+1 m$ from each end to the wire rope thimble & $1 / 2 "$ & combined rope ("tralla”) \\
& footrope & $13.75 m+1 m$ from each end to the wire rope thimble & $1 / 2 "$ & combined rope ("tralla") \\
\hline
\end{tabular}

Table 2. Measures in meshes each strip of netting of Japanese and Korean nets with their respective technical specifications.

\begin{tabular}{|c|c|c|c|c|c|c|c|c|c|}
\hline Model & Strip of netting & $\begin{array}{l}\text { No. } \\
\text { twine }\end{array}$ & $\begin{array}{c}\text { Otwine } \\
(\mathrm{mm})\end{array}$ & $\begin{array}{c}2 a^{a} \\
(\text { inch) }\end{array}$ & $N m b s^{b}$ & $N m b i^{c}$ & $N m h^{d}$ & Cutting rate & $\begin{array}{c}\text { Hung length of } \\
\text { netting }\end{array}$ \\
\hline \multirow{7}{*}{ Japanese } & Top panel & 21 & 1.9 & $2 ”$ & 190 & 10 & 180 & $1 N 1 B$ & $4 ”$ \\
\hline & Bottom panel & 21 & 1.9 & $2 ”$ & 190 & 35 & 155 & $1 N 2 B$ & $4 "$ \\
\hline & $J i b s$ & 21 & 1.9 & $2 ”$ & 47.5 & 47.5 & 240 & $A N$ & - \\
\hline & Small jib upper & 21 & 1.9 & $2 ”$ & 1 & - & 80 & $1 N 1 B+1 N 2 B 1 T 2 B$ & $4 "$ \\
\hline & $\begin{array}{l}\text { "Cuchilla" } \\
\text { lower }\end{array}$ & 21 & 1.9 & $2 ”$ & 1 & - & 80 & - & $4 ”$ \\
\hline & Overhang & - & - & - & - & - & 35 & - & - \\
\hline & Codend/bag & 42 & 2.5 & $13 / 4 "$ & 120 & 120 & 100 & - & - \\
\hline \multirow{7}{*}{ Korean } & Top panel & 21 & 1.9 & $2 ”$ & 170 & 1 & 170 & $1 N 1 B$ & $4 "$ \\
\hline & Bottom panel & 21 & 1.9 & $2 ”$ & 160 & 24 & 137 & $1 N 2 B$ & $4 "$ \\
\hline & $J i b s$ & 21 & 1.9 & $2 ”$ & 45 & 45 & 240 & $A N$ & - \\
\hline & Small jib upper & 21 & 1.9 & $2 ”$ & 1 & 47.5 & 70 & $1 N 1 B$ & $4 "$ \\
\hline & $\begin{array}{l}\text { "Cuchilla" } \\
\text { lower }\end{array}$ & 21 & 1.9 & $2 ”$ & 1 & 49.5 & 103 & $1 T 2 B$ & $4 "$ \\
\hline & Overhang & - & - & - & - & - & 35 & - & - \\
\hline & Codend/bag & 42 & 2.5 & $13 / 4 "$ & 120 & 120 & 100 & - & - \\
\hline
\end{tabular}

${ }^{a}$ Stretched mesh size, distance ( $N$ direction) between the centers of the 2 opposite knots of a stretched mesh.

${ }^{b}$ Number of meshes on the upper edge of the section (horizontal).

${ }^{c}$ Number of meshes in the bottom edge of the section (horizontal).

${ }^{d}$ Number of mesh section height (vertical).

The total sinker weight of a Japanese trawl is 30 $\mathrm{kg}$ and a large proportion of this weight is due to the footrope chain (3/8-inch diameter), which are arranged wavelike. Each chain wave is composed of 15 links that are 1 foot apart. In addition, three drop chains of 5 or 6 links each is placed every 12 chain waves it is also used a 22-m tickler chain of $3 / 8$ inch, which weighs $75 \mathrm{~kg}$. The dimensions and the material of the ropes, as well as the specific technical characteristics of each panel are presented in Tables 1 and 2 .

\subsection{Power transmission system}

Most of the winches have a mechanical-type transmission system, which consists of a belt drive system from the engine power take-off to an intermediate axle that transmits the movement to another chain drive system, which directly triggers the winch (Figure 3). Only one vessel of the fleet and all the Tolú fleet have hydraulic transmission systems.

The driven sprocket of the current transmission system has 50 teeth in the case of the Rice R800 $\mathrm{D}$, and 47 in the case of the Mc. Elroys - Hoists 505 (Table 3). When comparing the working parameters of the transmission systems used by the fleet with the ideal conditions, design problems in the gear ratio of the chain-driven transmission were detected. An ideal functioning would be achieved by reducing the number of teeth of the 
Table 3. Comparison of operating parameters on the transmission systems used in shrimp trawling fleet Colombia Caribbean Sea.

\begin{tabular}{ccccc}
\hline \multirow{2}{*}{ Operating parameters } & \multicolumn{2}{c}{ Present condition } & \multicolumn{2}{c}{ Ideal condition } \\
& Rice R800 D & Mc. Elroy-Hoists 505 & Rice R800D & Mc. Elroy-Hoists 505 \\
\hline rpm (power take-off) & $1400-1500$ & $1400-1500$ & 700 & 700 \\
Gear ratio $i_{1}$ & 2.70 & 2.38 & 2.70 & 2.38 \\
Gear ratio $i_{2}$ & 3.30 & 2.64 & 1.47 & 1.24 \\
Gear ratio $i_{3}$ & 4.18 & 5.36 & 4.18 & 5.36 \\
Total gear ratio $i_{t}=\left(i_{1} . i_{2} . i_{3}\right)$ & 37.24 & 35.37 & 16.59 & 16.51 \\
rpm (winches) & $35-45$ & $35-45$ & $35-45$ & $35-45$ \\
\hline
\end{tabular}

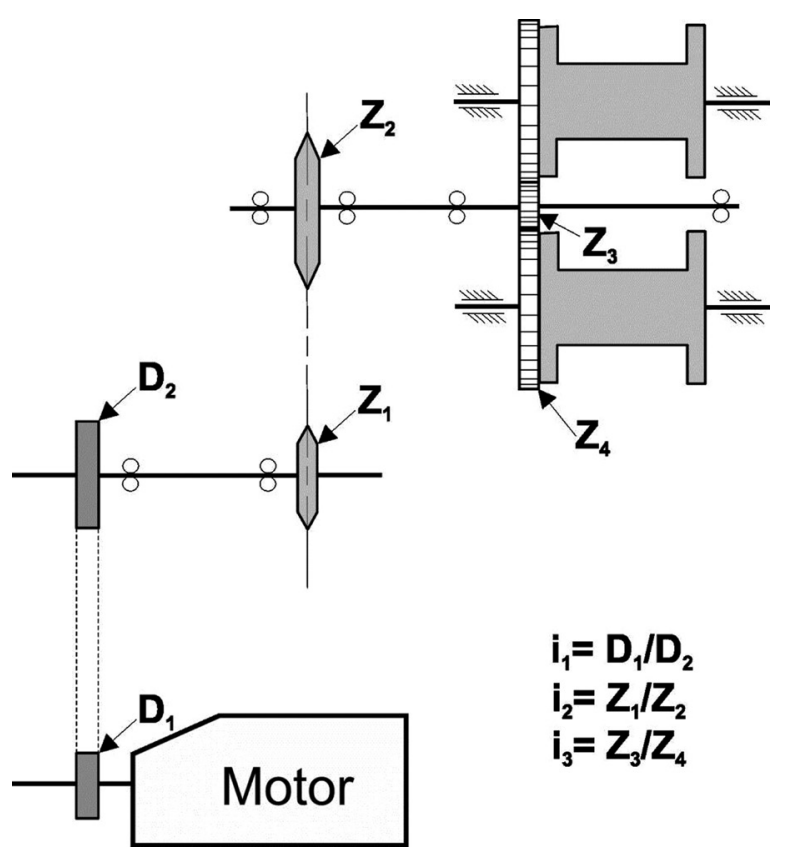

Figure 3. Kinematic scheme of transmissions system that power the winch of a typical shrimp vessel in the Caribbean of Colombia fleet.

driven sprocket to 22 in the case of the Rice R800 $\mathrm{D}$, and to 21 for the Mc. Elroys - Hoists 505. This is attributed to the fact that the transmission system is designed without taking into account the forces exerted during trawling operations. This requires the captains to use higher rpm values in the engine power take-off during hauling operations to reach the optimal hauling speed $(70 \mathrm{~m} / \mathrm{min})$, thereby reducing fuel consumption.

\subsection{Historical comparison of the ideal trawler}

The calculation of the fictitious area of the nets (A) showed that the semi-balloon trawl net had a greater area $\left(147.13 \mathrm{~m}^{2}\right)$ than that of the Korean trawl net $\left(75.44 \mathrm{~m}^{2}\right)$. Then, the forward resistance $\left(\mathrm{F}_{\mathrm{XA}}\right)$ was calculated for one of the four nets, taking into account the whole rigging, reaching values of 546.64 and $410.37 \mathrm{kgf}$ for the 46 -feet semi-balloon trawl net and the 37-feet Korean trawl net, respectively. On average, the towing speed of these trawlers is 2.8 knots. This value was used as the optimal towing speed for the purpose of calculating the traction force of the trawler $\left(\mathrm{F}_{\mathrm{TA}}\right)$. The results on the total pulling force exerted by the whole fishing equipment indicate oversizing of the Cartagena-based vessels both in dimensions and in engine power (Table 4).

Recent investigations have been carried out to establish the efficient use of fuel in fisheries (Suuronen et al., 2012). However, historically the implementation of these structural changes and those related to the deck machinery has not followed technical studies based on the analysis of the forward resistance due to the forces that oppose the fishing equipment. In fact, the results indicate that even in 1995 the machines as well as the vessels were oversized with regard to the fishing equipment used during that year. Until now, the only strategy to try to reduce operation costs has been to decrease the size of the trawl nets (37' HRL in 2005), without modifying the propulsion force and the structure of the trawler. The efficiency could be improved by merely changing the driven sprocket of the chain drive system. In this way, the hauling of the fishing equipment could be performed at a velocity of $70 \mathrm{~m} / \mathrm{min}$ (Czekaj, 1988), using only 700 of the $1500 \mathrm{rpm}$ that fishing captains usually use. This 
Table 4. Comparison between size and power of a typical vessel of the fleet and those calculated for an ideal vessel, depending on the type of trawling net used.

\begin{tabular}{lccc}
\hline Vessels characteristics & Typical vessel & $\begin{array}{c}\text { Ideal vessel with a 46'semi- } \\
\text { balloon shrimp trawl }\end{array}$ & $\begin{array}{c}\text { Ideal vessel with a 37' Korean } \\
\text { shrimp trawl }\end{array}$ \\
\hline Length (m) & 21.33 & 18.81 & 16.31 \\
Beam (m) & 6.66 & 6.07 & 5.26 \\
Draft (m) & 3.00 & 2.75 & 2.39 \\
Power (HP) & 450 & 317.82 & 238.80 \\
\hline
\end{tabular}

would represent a significant reduction in fuel consumption.

Taking into account the difficulties that the fleet is now experiencing, the need to promote technological development of the shrimp fishing trawling industry in the Colombian Caribbean by combining strategies of responsible and more efficient use of catch technologies and lower environmental impact is more pertinent than ever. Among said strategies, the following are highlighted: i) increasing the stretched mesh size in the body and wings of the net (Zúñiga et al., 2006), ii) use of by-catch reduction devices (Manjarrés et al., 2008) and iii) modifications in the footrope (Hannah \& Jones, 2000). Naturally, these measures would have to be accompanied by an efficient fishing management program based on the regulation of fishing effort (Beddington \& Rettig, 1983).

Other investigations aimed at the decrease of the use of fossil fuels used in the Colombian Caribbean trawl fishery were carried out by Zúñiga et al. (2006), who compared a vessel with traditional nets (42-feet Japanese) to another vessel $t$ with a new 55-feet net model, made of Ultracross Spectra (knotless netting technique), applying a pair-sample design. The results showed a lower forward resistance of the new net (436.7 $\mathrm{kgf}$ ), in comparison with the traditional net (457.5 kgf), along with a decrease in fuel consumption rate of $2.3 \mathrm{gal} / \mathrm{h}$, in spite of the larger net size of the new net. Regarding the ecological aspects, Escobar-Toledo \& Duarte (2009) established that these changes in the design and material constitute a mitigation strategy of the impact of the nets on the ecosystem, as although the area trawled was larger, the new net catched less by-catch than the traditional nets.
In spite of the experimental trials that have shown the suitability of the by-catch reduction devices (BRD) for attenuating the by-catch problem in the Colombian Caribbean trawl fishery (Manjarrés et al., 2008), these devices have not yet been implemented or regulated for the region. The use of Turtle Excluder Devices (TED) is mandatory in Colombia, according to Resolution 157 of 1993, issued by what was the National Fishing Agency at the time (Instituto Nacional de Pesca y Acuicultura - INPA) which was partially modified by Resolution 068 of March 1999. There are also certain remarkable private initiatives in the Gulf of Morrosquillo, consisting in using a new generation of netting materials, which have proved useful for reducing fuel consumption by up to $30 \%$ (Zúñiga et al., 2006).

\section{Conclusions}

The trawler vessels of the Colombian Caribbean trawl fleet are oversized for the fishing equipment that is currently being used. Furthermore, chain transmission system could be improved by reducing the number of teeth of the driven sprocket. In this way, fuel consumption rate could be significantly reduced. Given that it is economically impossible to change the vessels for other smaller ones, a feasible alternative would be to use fishing equipment specifically designed for the installed power and made of more resistant and lighter materials, and with design features that lead to a reduction in the impact on by-catch.

\section{Acknowledgements}

This research was conducted in the framework of the projects: "VFA" (cod.1117-09-13273) and "ITFI", with financial support from COLCIENCIAS, 
Universidad del Magdalena, INCODER, GEFFAO (EP/GLO/201/GEF), Armadores pesqueros and Universidad Nacional de Colombia.

\section{References}

Arzuaga, C., \& Torres, E. (1990). Caracterización de la flota pesquera artesanal y semi-industrial que opera en el Golfo de Morrosquillo. Revista Cientifica, Técnica e Informativa INDERENA-CIP 3, 77-92.

Bonilla de la Corte, A. (1979). Teoría del buque. Cádiz: Bonilla de la Corte.

Beddington, J.R., \& Rettig, R.B. (1983). Approaches to the regulation of fishing effort. Rome. Food \& Agriculture Fao.

Bucki, F. (1981). Principios generales de cálculo en las artes de pesca. Serie de materiales didácticos en ciencia y tecnología del mar. México: Secretaría de Educación Pública.

Bucki, F. (1984). Diseño de las artes de pesca y arrastre. 1ra. Parte. Serie de materiales didácticos en ciencia y tecnología del mar. México: Dirección General de Ciencia y Tecnología del Mar.

Buelvas, J., \& Guerrero, C. (1996). Equipo pesquero y motriz de la flota camaronera del Caribe colombiano. Tesis pregrado, Facultad de Ingeniería, Universidad del Magdalena, Santa Marta, Colombia.

CAMESA. (2000). Catálogo de cables de acero. México D.F., México.

Escobar-Toledo, F., \& Duarte, L.O. (2009). Reducción de la pesca acompañante en una pesquería tropical de camarón: resultados experimentales del cambio en el material de las redes de arrastre. Proceedings of the 62nd Gulf and Caribbean Fisheries Institute 62, 83-89.

Fuentes, D. \& Portugal, R. (1973). Poder de pesca de la flota camaronera de Campeche. México, INP.
García-Caudillo, J.M., \& Gómez-Palafox, J.V. (2005). La pesca industrial de camarón en el Golfo de California: Situación económico e impactos socio-ambientales. Conservación Internacional 1,1-17.

Hannah, R.W., \& Jones, S.A. (2000). By-catch reduction in an Ocean shrimp trawl from a simple modification to the trawl footrope. Journal of Northwest Atlantic Fishery Science 27, 227-233.

Koyama, T. (1971). A calculation method for matching trawl gear to towing power of trawlers. In: H. Kristjonsson (editor), Modern fishing gear of the world. Fishing News Books. (Part 3).

Martínez, S. (1978). Análisis del desarrollo pesquero en la costa norte de Colombia. Memorias III Seminario Nacional de Ciencias del Mar. COLCIENCIAS.

Mora, J. (1988). Análisis de la pesca de camarón de aguas someras (Penaeus F. notialis y Penaeus brasiliensis) efectuada por la flota camaronera del Caribe Colombiano. Informe técnico INDERENA CIP, Bogotá, Colombia.

Parente, J., Fonseca, P., Henriques, V., \& Campos, A. (2008). Strategies for improving fuel efficiency in the Portuguese trawl fishery. Fisheries Research 93, 117-124.

Piñeros, V., \& Sieguert, P. (1981). La pesquería de camarón en el Caribe colombiano. Tesis pregrado, Facultad Ciencias del Mar. Universidad Jorge Tadeo Lozano, Cartagena, Colombia.

Shawyer, M. (1997). Conversión de barcos camaroneros. Análisis de componentes estratégicos del sector pesquero colombiano. Formulación de políticas. Programa Cooperación Técnica FAO. Bogotá, Colombia.

Suuronen, P., Chopin, F., Glass, C., Løkkeborg, S., Matsushita, Y., Queirolo, D., \& Rihan, D. (2012). Low impact and fuel efficient fishing. Looking beyond the horizon. Fisheries Research 120, 135-146. 
van Marlen, B. (2003). Improving the selectivity of beam trawls in The Netherlands: The effect of large mesh top panels on the catch rates of sole, plaice, cod and whiting. Fisheries Research 63, 155-168.

van Marlen, B. (2008). Energy Saving in Fisheries (ESIF) FISH/2006/17 LOT3. Final Report. IMARES Report number C002/08.

Wileman, D. (1984). Project "Oilfish". Investigation of the Resistance of Trawl Gear. The Danish Institute of Fisheries Technology.

Zúñiga, H., Altamar, J., \& Manjarrés, L. (2004). Caracterización tecnológica de la flota de arrastre camaronero del Mar Caribe de Colombia. Technical Report. REBYC (EP/GLO/201/GEF). FAO, UNEP.

Zúñiga, H., Sánchez, J., Altamar, J., \& Manjarrés, L. (2006). Evaluación técnica y económica de innovaciones en el sistema de arrastre de la flota industrial camaronera del Caribe colombiano. In: H. Zúñiga, et al. (editor), Evaluación de innovaciones en la tecnología de captura de la pesquería industrial de arrastre camaronero del Caribe colombiano, con fines ecológicos y de productividad. Informe Técnico, Universidad del Magdalena-INCODER-DISTAGEF/FAOINVEMAR, Santa Marta. 